\title{
Repression of potential nitrification activities by matgrass sward species
}

\author{
Nina Antonia Cornelia Smits • Roland Bobbink • \\ Hendrikus J. Laanbroek • Aline J. Paalman • \\ Mariet M. Hefting
}

Received: 2 March 2010 / Accepted: 13 August 2010 /Published online: 1 September 2010

(C) The Author(s) 2010. This article is published with open access at Springerlink.com

\begin{abstract}
Soil nitrification is a key process in regulating the relative availability of the various inorganic $\mathrm{N}$ forms to plants. In the current study, we investigated the effect of different plant species on numbers of ammoniaoxidizing microbial cells by measuring the potential nitrification activity (PAA). Soil from matgrass sward and from calcareous grassland was collected in the field and four characteristic plant species of each vegetation type were cultivated from seed. These plant species grew for 4 months in the two soil types. After those 4 months, PAA were significantly higher in calcareous soil compared to the matgrass sward soil and the
\end{abstract}

Responsible Editor: Euan K. James.

N. A. C. Smits · H. J. Laanbroek · A. J. Paalman •

M. M. Hefting

Landscape Ecology, Institute of Environmental Biology,

Utrecht University,

P.O. Box 80084, 3508 TB Utrecht, The Netherlands

N. A. C. Smits $(\bowtie)$

Alterra, Wageningen University and Research, P.O. Box 47, 6700 AA Wageningen, The Netherlands e-mail: Nina.Smits@wur.nl

R. Bobbink

B-ware Research Centre BV, Radboud University, P.O. Box 9010, 6500 GL Nijmegen, The Netherlands

H. J. Laanbroek

Department of Microbial Ecology,

Netherlands Institute of Ecology (NIOO-KNAW),

Rijksstraatweg 6,

3631 AC Nieuwersluis, The Netherlands presence of matgrass sward species had significantly decreased PAA in this soil. In soils from matgrass stands, PAA were much lower, and no effect of the different plant species could be detected. Plant biomass of the calcareous grassland species was overall positively correlated with PAA, whereas for matgrass plant species a negative trend was found. We conclude that matgrass sward plant species had a clear repressing effect on the potential ammonia-oxidizing activity in calcareous grassland soil within this 4-month growth experiment. The observed repression of PAA is in accordance with earlier field observations of PAA in the different vegetation zones, where repressed PAA and significant higher ammonium to nitrate ratios were observed in the matgrass sward vegetation compared to the other vegetation zones. Major findings of this study indicate that plant species can influence the nitrification potential of their habitats, i.e. certain species can repress nitrification potential and others can increase nitrification potential of their habitats.

Keywords Potential ammonia-oxidising activities . Nitrification inhibition - Ammonium toxicity Calcareous grassland $\cdot$ Mesobromion $\cdot$ Nardo-Galion . Nitrate production

\section{Introduction}

In the Netherlands, species-rich grasslands occur on hill slopes in South Limburg in a unique vegetation 
gradient where loess and acid gravel have been deposited by the river Meuse on top of calcareous substrate. This local geomorphology resulted in a vegetation gradient with acid grasslands on the acid gravel deposits on the upper hill slopes, more buffered matgrass swards on thin layers of loess on top of acid gravel deposits in the middle reach, and calcareous grasslands on calcareous outcrops beneath. Potentially, these nutrient-poor grasslands on hill slopes are one of the most species-rich ecosystems in the Netherlands (Willems 2001; WallisDeVries et al. 2002), but from the beginning of twentieth century a strong decline in species richness was observed, due to the abandonment of traditional land use practices, like shepherding and hay making (Willems 1990; Poschlod and WallisDeVries 2002) and the effects of atmospheric nitrogen deposition (Bobbink et al. 1998; Bakker and Berendse 1999; Stevens et al. 2004; Clark and Tilman 2008).

Increased inputs of nitrogen in these grasslands may have a direct eutrophication effect on the vegetation leading to changes in competitive interactions and shift in plant species composition (Bobbink 1991). In the acidic part of these grasslands, both soil acidification and shifts in the dominant form of inorganic nitrogen, e.g. nitrate or ammonium, are of main importance for the observed effects of $\mathrm{N}$ deposition (e.g. Bobbink and Lamers 2002; Kleijn et al. 2008; De Graaf et al. 2009; Dupré et al. 2009), whereas acidification and shifts in the dominant form of inorganic nitrogen do not play a major role in calcareous grasslands (Bobbink and Roelofs 1995). Increased ammonium concentrations in the soil solution can cause toxicity in plant species characteristic for acidic to slightly buffered habitats (De Graaf et al. 1998; Britto and Kronzucker 2002; Dorland et al. 2003, Van den Berg et al. 2005, 2008). In contrast, no negative effect of ammonium is observed for grass species which are known to invade these vegetation types at high $\mathrm{N}$ deposition rates. Soil nitrification is a key process in regulating the relative availabilities of the differential $\mathrm{N}$ forms to plants, and therefore plays a crucial role in the effects of enhanced $\mathrm{N}$ inputs on the composition of the vegetation.

Recently, a clear spatial pattern has been observed in the dominant form of inorganic nitrogen in the soil of the above-mentioned South Limburg grassland gradient: nitrate concentrations were significantly lowest in the matgrass sward, whereas ammonium concentrations decreased from the acid to the calcareous zone. Moreover, the ammonium to nitrate ratio was significantly higher in the matgrass swards zone $(\mathrm{pH} 6.1)$ in comparison to the acid grassland $(\mathrm{pH} 5.1)$ and the calcareous grassland ( $\mathrm{pH} 8.0$ ), with averages of 8.7, 2.9 and 1.0 respectively. The potential ammonia-oxidising activity, a measure for the number of actively ammoniaoxidising microbial cells (Verhagen et al. 1992), turned out to be significantly lower in the matgrass sward, when compared to the PAA in the acid grassland and the calcareous grassland (Smits et al. 2010). Molecular analysis of the ammonia-oxidizing betaproteobacterial communities based on the $16 \mathrm{~S}$ rRNA gene showed no major differences in the diversity between these three vegetation zones (Smits et al. 2010). We are aware that, in general, lower $\mathrm{pH}$ correlates to lower PAA, but found that in this research gradient, nitrification was lowest at intermediate $\mathrm{pH}$ level. This gave reason for further research.

The observed repression of the potential nitrification activity in the matgrass sward may be explained by exudation of biological nitrification inhibitors (BNI) by plants. Up to now, several indications for exudation of BNI have been demonstrated in crop plant species (Subbarao et al. 2007a, b; Zakir et al. 2008; Subbarao et al. 2009a, b) and Hyparrhenia sp. dominated savannas (Lata et al. 1999, 2000, 2004). In the current article, we focus on the vegetation level. To investigate the extent to which the characteristic grassland vegetation affects potential nitrification, characteristic species of both vegetation types grew on both soils of the two plant communities. The objective of this study was to examine if characteristic plant species of both matgrass sward and calcareous grasslands have an influence on the potential nitrification activities in the soil. We hypothesise that the repression of potential nitrification activity observed in the field (Smits et al. 2010) is due to biological nitrification inhibition by typical matgrass sward plant species.

\section{Materials and methods}

Description of the research habitats

The two vegetation types that are used in this study comprise matgrass sward vegetation (Nardo-Galion saxatilis, Swertz et al. 1996) on dystric eutrudept soils and calcareous grassland (Mesobromion erecti, 
Schaminee and Willems 1996) on a typic to rendollic eutrudept soils (Soil Survey Staff 1999). Along the whole gradient, (para)lithic contacts occur.

\section{Experimental setup}

A pot experiment was set up in the greenhouse, in which eight selected plant species grew for 4 months from October 2007 to March 2008 on soil from the matgrass sward zone and on soil from the calcareous grassland zone. Soil samples of the upper $10 \mathrm{~cm}$ (as this contains most roots) were collected in the matgrass swards and in the calcareous grassland at the Bemelerberg nature reserve (the Netherlands, $50^{\circ}$ $\left.51^{\prime} \mathrm{N}, 5^{\circ} 46^{\prime} \mathrm{O}\right)$. The soil was stored at $4^{\circ} \mathrm{C}$ and processed within 2 days after collection. Homogenized soil of each soil type was put into 11 pots. Seeds of four characteristic species of matgrass swards, and of four typical species of calcareous grassland were collected from different local nature reserves. Species selection took place based on seed availability and family similarity. For comparison across the two soil types, similar families (i.e. Asteraceae, Poaceae and Lamiaceae) were used for three out of four species. For matgrass swards, the selection resulted in Hieracium umbellatum, Succisa pratensis, Danthonia decumbens and Stachys officinalis as characteristic species, whereas Leontodon hispidus, Sanguisorba minor, Briza media and Thymus pulegioides were the selected species of calcareous grassland. Seeds were germinated in the greenhouse in standard potting soil, and 4-weeks-old seedlings were used in the experiment. The nomenclature was used according to Van der Meijden (2005) for the plant species, and Schaminée et al. (1996) for the vegetation.

Of every species, four seedlings were planted in pots with matgrass sward soil $(n=4)$ and in pots with calcareous grassland soil $(n=5)$. As there was not sufficient matgrass sward soil collected for five replicates, only four replicates were used with this soil type. Pots without seedlings were included as controls ( $n=5$ for calcareous grassland soil and $n=4$ for matgrass sward soil). In total 45 pots with calcareous grassland soil were used and 36 pots with matgrass sward soil. All 81 pots were randomly placed in the greenhouse with a 16-h photoperiod with temperatures were according to the greenhouse climate, and watered four times a week during the whole experiment with rainwater. The used rainwater was analysed twice during the experiment for nitrate and ammonium concentrations to check on possible extra nitrogen input. In the first month, different plant species started to show interveinal chlorosis on both soil types. Spraying with $0.05 \mathrm{M}$ iron (Fe-EDDHA) and $0.02 \mathrm{M}$ manganese (Mn-DTPA; Brinkman Agro $\mathrm{BV}, \mathrm{NL})$ removed these effects. The treatment was repeated three times during the experiment.

Soil nutrient analysis

At the beginning of the experiment, soil of each grassland type was homogenized and extracted (15 g, $n=5)$ on a rotary shaker for $1 \mathrm{~h}(100 \mathrm{rpm})$ with $100 \mathrm{ml}$ demineralised water for the determination of $\mathrm{pH}$ and nitrate concentrations. An extraction with $100 \mathrm{ml} 0.2 \mathrm{M} \mathrm{KCl}$-solution was used for the measurement of ammonium concentrations. The soil suspensions were centrifuged for $5 \mathrm{~min}$ at 4,000 rpm. Supernatants were filtered through a Whatman GF/Cfilter and stored at $-20^{\circ} \mathrm{C}$ until further analysis. Soil moisture content was determined after drying at $105^{\circ} \mathrm{C}$ for $48 \mathrm{~h}$. Nitrate (nitrite plus nitrate) and ammonium concentrations in the soil extracts were determined colorimetrically using a continuous flow analyser (Skalar 40, Skalar Analytical BV, Breda, the Netherlands). The nitrate and ammonium concentrations in the pore water in the pots were measured bi-weekly during the growth experiment through small rhizon samplers of $200 \mathrm{ml}$ (Eijkelkamp, the Netherlands) in 22 stratified randomly chosen pots. At each sampling moment, every combination of soil/ plant species was included and three of the controls were also measured.

Potential ammonia-oxidising activities

Potential ammonia-oxidising activities (PAA) were determined at the start and at the end of the experiment in $250 \mathrm{ml}$ Erlenmeyer flasks containing slurries of $15 \mathrm{~g}$ fresh, sieved $(4 \mathrm{~mm})$ soil in $100 \mathrm{ml}$ buffered medium with $2 \mathrm{mM}\left(\mathrm{NH}_{4}\right)_{2} \mathrm{SO}_{4}$ (after Hart et al 1994). The buffer was composed of $2 \mathrm{mM}$ phosphate buffer (an equimolar mixture of $\mathrm{KH}_{2} \mathrm{PO}_{4}$ and $\mathrm{K}_{2} \mathrm{HPO}_{4}$, adapted to the prevailing soil $\mathrm{pH}$ ), because preliminary experiments had shown that the PAA in samples were affected by the $\mathrm{pH}$ value of the slurries in which these activities were measured. Hence, PAA were determined 
at $\mathrm{pH}$ values comparable with the original soil $\mathrm{pH}$ (i.e. 5.4 for matgrass swards and 8.0 for calcareous grassland). During the PAA measurements, the slurries were permanently shaken on a rotary shaker (RO 20, Gerhardt, Bonn, Germany; $100 \mathrm{rpm}$ ) in the dark at a temperature of $27^{\circ} \mathrm{C}$. Sub-samples of $3 \mathrm{ml}$ were taken at $t=0 \mathrm{~h}, 2 \mathrm{~h}, 4 \mathrm{~h}, 6 \mathrm{~h}, 21 \mathrm{~h}, 27 \mathrm{~h}, 51 \mathrm{~h}, 74 \mathrm{~h}, 98 \mathrm{~h}$, $122 \mathrm{~h}$ and $146 \mathrm{~h}$, and centrifuged for $5 \mathrm{~min}$ at 13,000 rpm (Biofuge pico, Heraeus instruments, South Plainfield, USA), decanted, and frozen $\left(-20^{\circ} \mathrm{C}\right)$ till analysed. At each sampling time, the $\mathrm{pH}$ of the incubation medium was checked, and set to its original value with $0.1 \mathrm{~N} \mathrm{NaOH}$ or $0.1 \mathrm{~N} \mathrm{HCl}$, if necessary. Concentrations of nitrite plus nitrate in the subsamples were measured on a continuous flow analyser (Skalar 40, Skalar Analytical BV, Breda, the Netherlands). PAA were calculated from the changes in nitrite plus nitrate concentrations in time, using linear regressions. The slope of the regression lines was used as a measure for the PAA. The average $\mathrm{R}^{2}$ of the used linear regressions of the PAA at the end of the experiment was 0.99 for matgrass sward soils (s.d. 0.01), and 0.99 for calcareous grassland soils (s.d. 0.01).

Plant growth

To analyse systematic differences in plant growth between the two soil types, above- and belowground biomass of all plants was harvested after 4 months of growth, dried at $70^{\circ} \mathrm{C}$ and weighted.

\section{Statistics}

The measurements of the chemical characteristics of the soil and the PAA at the beginning of the experiment were analysed with a non-parametric Mann-Whitney U Test. The PAA at the end of the experiment was tested with a two-way ANOVA. As there was a clear interaction effect (soil * species), both soil types were further analysed with a one-way ANOVA, including a Tukey-b post-hoc test on the group level and on the species level, as both datasets were normally distributed and homogeneity of variance (Levene's Test) could be assumed. Nitrate and ammonium concentrations in the pore water samples of the experimental pots (rhizon samples) were analysed by repeated measurements analyses. For both parameters, the sphericity could not be assumed (Mauchly's Test of Sphericity). Therefore, the Greenhouse Geisser epsilon was used. Biomass production of the separate species between both soil types were tested with a non-parametric Mann-Whitney $\mathrm{U}$ Test, and the correlation of the biomass of the plants and the found PAA was tested with a non-parametric (Spearmans rho) correlation. All statistical analyses were carried out in PASW statistics 17.0.

\section{Results}

Chemical characteristics of the soil

At the start of the experiment, the $\mathrm{pH}$ values (in demineralised water) of the two soil types were significantly different: on average 5.4 in matgrass sward soil, and 8.0 in calcareous grassland soil (Table 1). Furthermore, nitrate concentrations were significantly higher and ammonium concentrations and the ammonium:nitrate ratio were significantly lower in the pots with calcareous grassland soil, compared to those with matgrass sward soil (Table 1).

The nitrate and ammonium concentrations in the pore water samples of the experimental pots (rhizon samples) were analysed in both soil types with repeated measurements analysis (GLM, Table 2). Three plant groups were distinguished: matgrass sward species, calcareous grassland species and no plant species (controls). Ammonium concentrations only turned out to be significantly different between soil types. Matgrass sward soil contained more ammonium than calcareous grassland soil ( $P=0.006$, Table 2$)$, but there was no effect of time and measured ammonium concentrations were present during the whole experiment with at least $0.1 \mathrm{mg} \cdot \mathrm{kg}^{-1}$ dry soil ammonium-nitrogen in the pore water. Therefore, ammonium was never limiting the nitrifiers in the soils during the growth experiment. On average, $2 \mathrm{mg} \cdot \mathrm{kg}^{-1}$ dry soil ammonium-nitrogen was available during the experiment in matgrass sward soil, whereas calcareous soil only contained $0.3 \mathrm{mg} \cdot \mathrm{kg}^{-1}$ dry soil of available ammonium-nitrogen (Table 2). Nitrate concentrations only showed significant differences for the interaction time ${ }^{*}$ soil (Table 2 ) and on average $216 \mathrm{mg} \cdot \mathrm{kg}^{-1}$ and $186 \mathrm{mg} \cdot \mathrm{kg}^{-1}$ dry soil nitratenitrogen was present during the experiment in the matgrass sward and calcareous grassland soil, respectively. Nitrate-nitrogen in the controls was increasing during the experiment in matgrass sward soil, indicating nitrification activity and confirming the higher PAA measured in the controls at the end of the 
Table 1 Soil characteristics at the beginning of the experiment (averages and in brackets the standard deviations, $n=5$ )

\begin{tabular}{lll}
\hline & Calc. soil $(n=5)$ vs. Matgrass sward soil $(n=5)$ & Matgrass sward soil \\
\hline $\mathrm{pH}$ demi & & $5.4(0.4)$ \\
$\mathrm{N}$ in $\mathrm{NO}_{3}$ demi $\left(\mathrm{mg} \mathrm{kg}^{-1}\right.$ dry soil)** & $8.0(0.1)-5.4(0.4)^{* *}$ & $2.5(1.2)$ \\
$\mathrm{N}$ in $\mathrm{NH}_{4 \mathrm{KCl}}\left(\mathrm{mg} \mathrm{kg}^{-1}\right.$ dry soil)* & $6.4(1.1)-2.5(1.2)^{* *}$ & $12.9(6.4)$ \\
Ammonium:nitrate ratio** & $2.4(2.3)-12.9(6.4)^{*}$ & $7.7(7.8)$ \\
PAA_start experiment $\left(\mathrm{mg} \mathrm{l}^{-1} \mathrm{~h}^{-1}\right)^{* *}$ & $0.4(0.4)-7.7(7.8)^{* *}$ & $0.08(0.04)$ \\
\hline
\end{tabular}

Significance level (Mann-Whitney U Test): ${ }^{*} P<0.01 ; * 0.01>P<0.05 ;$ n.s. not significant. The $\mathrm{R}^{2}$ of the calculated regression lines for Potential Ammonia-oxidising Activities at the start of the experiment (PAA_start) was on average 0.98 (st. dev. 0.03 )

experiment (data not shown). Nitrate concentrations in the pore water samples were on average over 500 times higher than the corresponding concentrations in the rainwater samples, whereas ammonium concentrations were more than three times higher (data not shown).

Potential ammonia-oxidising activities (PAAs)

The PAAs at the start of the experiment were significantly lower (Independent samples Test) in the matgrass swards soils compared to the calcareous grassland soils, with on average 0.08 vs. $0.42 \mathrm{mg} \mathrm{N}$ (nitrite plus nitrate) $\mathrm{l}^{-1} \mathrm{~h}^{-1}$, respectively (Table 1 ). At the end of the experiment, the PAAs of the soils without plants were still significantly different between the two soil types with 0.16 (s.d. 0.03 ) and 0.34 (s.d. 0.03 ) $\mathrm{mg} \mathrm{N}$ (nitrite plus nitrate) $\mathrm{l}^{-1} \mathrm{~h}^{-1}$ in the matgrass sward and the calcareous grassland soil, respectively. Two-way ANOVA revealed significant effects for soil type (lower PAA in matgrass sward) and species level, but also a strong interaction effect for soil $*$ species, and therefore further analysis of the data was carried out for both soil types separately with a one-way ANOVA.

For the matgrass sward soil, analysis of the three plant groups (matgrass sward species, calcareous grassland species and no species) did not show significant differences $(P=0.068)$ with slightly higher PAA in the pots without plant species. Analysis for the different species did also not show significant differences between the nine groups (four matgrass sward species, four calcareous grassland species and the control, $P=0.052$ ). However, the PAA in calcareous soil data did show significant differences between the

Table 2 Summary of statistical analyses (GLM, repeated measurement analysis) for ammonium and nitrate concentrations in pore water samples during the experiment

\begin{tabular}{lll}
\hline & Ammonium & Nitrate \\
Time $(n=6)$ & $F=0.770, P=0.458$ n.s. & $F=1.088, P=0.360$ n.s. \\
Plant & $F=1.092, P=0.369$ n.s. & $F=2.164, P=0.161 \mathrm{n} . \mathrm{s}$. \\
Soil & $F=11.833, P=0.006^{* *}$ & $F=0.646, P=0.439$ n.s. \\
Time x Plant & $F=1.539, P=0.235$ n.s. & $F=1.805, P=0.151 \mathrm{n} . \mathrm{s}$. \\
Time x Soil & $F=1.248, P=0.304$ n.s. & $F=3.935, P=0.027 *$ \\
Plant x Soil & $F=1.397, P=0.288$ n.s. & $F=1.993, P=0.183$ n.s. \\
Time x Plant x Soil & $F=1.209, P=0.337$ n.s. & $F=0.421, P=0.817$ n.s. \\
Soil type & Matgrass sward-Calcareous & Matgrass sward-Calcareous \\
Av. Conc. (s.e.) & $2.002(0.338)-0.324(0.351)$ & $215.666(26.032)-185.520(27.015)$ \\
\hline
\end{tabular}

Significance level: $* * 0.001>P \leq 0.01 ; * 0.01>P<0.05 ;$ n.s. not significant. At the end of the table, the average concentrations for both soil types are presented $\left(\mathrm{N}\right.$ in ammonium and $\mathrm{N}$ in nitrate in $\mathrm{mg} \cdot \mathrm{kg}^{-1}$ dry soil) with the standard error between brackets 
plant groups $(P<0.001)$, with significant lower PAA for matgrass sward plants than for calcareous plants and controls. When testing the species separately, five homogeneous subsets could be distinguished (Fig. 1, indicated with different letters). Thus, the PAA in calcareous soils did show distinct differences for the different species, with significant less nitrification in pots with matgrass sward species and with PAA comparable to the controls when calcareous grassland species were present (Fig. 1).

Plant growth

In general, average above-ground, below-ground and total plant biomass were all significantly higher on calcareous soils. The matgrass sward species $H$. umbellatum showed a significantly higher $(p<0.05)$ above- and below-ground and total biomass in pots with calcareous soil compared to the matgrass sward soil. The calcareous grassland species $T$. pulegioides and $S$. minor showed a significantly higher $(p<0.05)$ above-ground biomass in the pots with calcareous soil compared to the matgrass sward soil (Table 3) and the calcareous grassland species L. hispidus and $T$. pulegioides showed a significantly higher belowground in pots with calcareous grassland soil. $T$. pulegioides also showed a significantly higher total biomass in pots with calcareous grassland soil. The other species did not show any significant differences in dry weights for both soil types.

Above-ground and total plant biomass were significantly positive correlated (Spearman's rho correlation) to PAA for all data together (Table 4). The biomass of the calcareous grassland species did not show a significant correlation with PAA when grown on matgrass sward or calcareous grassland soils separately, but the correlation between the biomass of these plant species and PAA was significantly positive when both soil types were taken together (Table 4, Fig. 2, continuous lines). The biomass of the matgrass sward plants did only show a negative trend, but no significant correlation with PAA, except for the below-ground and total biomass of the plants grown on matgrass sward soil (Table 4, Fig. 2, dotted lines).

The whole set of plants grown on calcareous grassland soil also was significantly positively correlated to above-ground and total plant biomass (Table 4), whereas no significant correlation was observed for the whole set of plants grown on the matgrass sward soil (Table 4) although a negative trend was visible (Fig. 2, dotted lines).

\section{Discussion}

The difference between plants from the matgrass swards and those from the calcareous grasslands with respect to potential ammonium oxidation activities was only observed on calcareous soil (Fig. 1). On soil from the matgrass sward itself, no differences in PAA between plant species from both vegetation types were observed. This latter might be related to the significantly lower nitrification potential observed in the matgrass soil at the start of the growth experiment compared to the calcareous soil (Table 1), but the

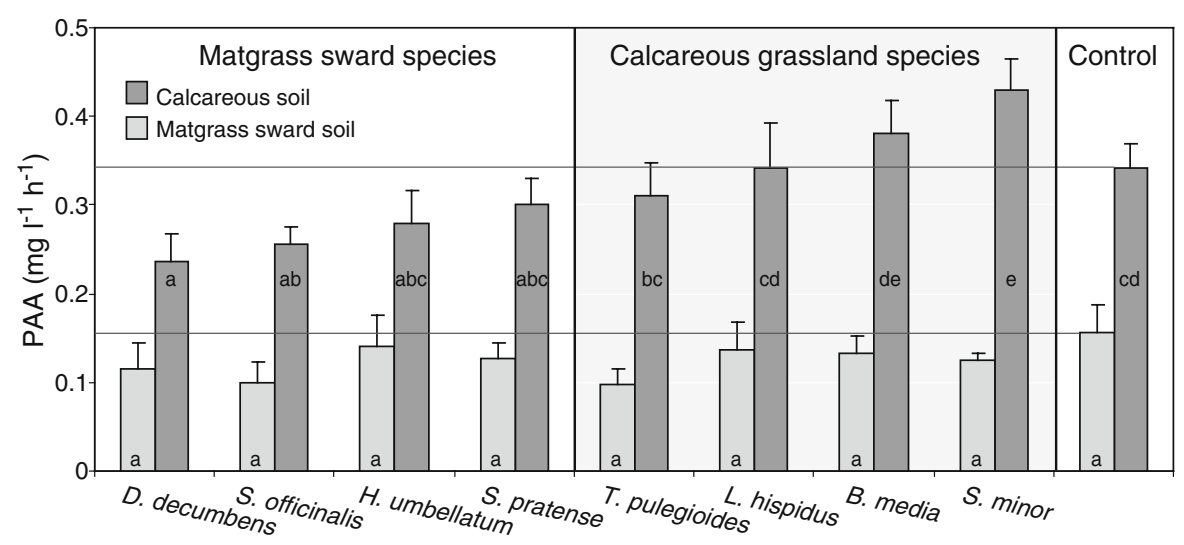

Fig. 1 Potential Ammonia-oxidising Activity (PAA, in $\mathrm{mg} \mathrm{l}^{-1} \cdot \mathrm{h}^{-1}$ ) at the end of the 4-month growth experiment in both soils for all species and controls without plants present. The letter codes indicate significant differences (at the $P<0.05$-level, ANOVA), and the horizontal lines represent the average value for the controls (soil without plant species) 
Table 3 The above-ground, below-ground and total biomass $(\mathrm{g})$ of the plants grown on calcareous grassland and on matgrass sward soils as determined at the end of the experiment

\begin{tabular}{|c|c|c|c|}
\hline & Above-ground biomass in & Below-ground biomass in & Total biomass in \\
\hline Species & Calc. soil-Matgrass sward soil & Calc. soil—Matgrass sward soil & Calc. soil-Matgrass sward soil \\
\hline \multicolumn{4}{|c|}{ Matgrass sward species } \\
\hline H. umbellatum & $0.92( \pm 0.26)-0.43( \pm 0.17)^{*}$ & $0.78( \pm 0.25)-0.19( \pm 0.53)^{*}$ & $1.70( \pm 0.37)-0.63( \pm 0.17)^{*}$ \\
\hline D. decumbens & $1.99( \pm 0.64)-1.98( \pm 0.41)$ n.s. & $0.80( \pm 0.22)-1.28( \pm 0.57)$ n.s. & $2.79( \pm 0.85)-3.25( \pm 0.96)$ n.s. \\
\hline S. officinalis & $1.30( \pm 0.19)-1.32( \pm 0.10)$ n.s. & $0.82( \pm 0.08)-0.80( \pm 0.32)$ n.s. & $2.13( \pm 0.25)-2.12( \pm 0.40)$ n.s. \\
\hline S. pratensis & $1.46( \pm 0.43)-1.22( \pm 0.15)$ n.s. & $0.39( \pm 0.30)-0.33( \pm 0.06)$ n.s. & $1.86( \pm 0.71)-1.55( \pm 0.13)$ n.s. \\
\hline \multicolumn{4}{|c|}{ Calcarous grassland species } \\
\hline L. hispidus & $1.50( \pm 0.14)-1.35( \pm 0.29)$ n.s. & $0.68( \pm 0.19) 0.27( \pm 0.04)^{*}$ & $2.18( \pm 0.30)-1.62( \pm 0.32)$ n.s. \\
\hline B. media & $1.82( \pm 0.35)-1.31( \pm 0.59)$ n.s. & $0.60( \pm 0.13) 0.66( \pm 0.22)$ n.s. & $2.42( \pm 0.47)-1.97( \pm 0.80)$ n.s. \\
\hline T. pulegioides & $2.96( \pm 0.89)-1.14( \pm 0.36)^{*}$ & $0.76( \pm 0.24) 0.35( \pm 0.15)^{*}$ & $3.72( \pm 0.94)-1.49( \pm 0.49)^{*}$ \\
\hline S. minor & $2.58( \pm 0.34)-1.61( \pm 0.57)^{*}$ & $1.38( \pm 0.25) 1.22( \pm 0.34)$ n.s. & $3.96( \pm 0.47)-2.83( \pm 0.86)$ n.s. \\
\hline
\end{tabular}

Significant differences (Mann-Whitney U Test) are shown with * for $0.01<P>0.05$, and $* * P<0.01$; n.s. not significant. Shown are the averages $(\mathrm{g})$ and standard deviations are between in brackets

inhibitory effect of Biological Nitrification Inhibition (BNI) can also vary with soil type (Gopalakrishnan et al. (2009).

In the absence of plants, the PAA in the calcareous soil decreased on average by $19 \%$, whereas the PAA in the controls of the matgrass sward soil increased by $93 \%$ on average, but was still well below the PAA measured in the calcareous soil. Although PAA had increased in the absence of plants during the growth period of 4 months in matgrass sward soil, the significantly lower $\mathrm{pH}$ probably prevented a fast increase in PAA, which may have masked a possible effect of the plants on the development of the PAA. The time period of 4 months may not have been long enough to overcome the originally low population size of the ammoniaoxidizing betaproteobacteria, although the PAA in matgrass sward soil was increasing during the experiment. An experimental period longer than 4 months might have shown the same differences between both plant groups in the matgrass sward soil as observed now for the calcareous soil. The restricted experimental period might also have been responsible for the

Table 4 Correlation coefficients of potential ammonia-oxidation activities (PAA) with plant biomass parameters (Spearman rho correlation)

\begin{tabular}{|c|c|c|c|c|c|}
\hline Soil type & Plant type & $\mathrm{N}$ & DW above & DW below & DW total \\
\hline Both & Both & 72 & $0.417 * * *$ & 0.203 n.s. & $0.374 * *$ \\
\hline Both & Calcareous grassland & 36 & $0.612 * * *$ & $0.461 * *$ & $0.597 * * *$ \\
\hline Both & Matgrass sward & 36 & -0.024 n.s. & -0.081 n.s. & -0.027 n.s. \\
\hline Calcareous soil & Both & 40 & $0.424 * *$ & 0.092 n.s. & $0.372 *$ \\
\hline Calcareous soil & Calcareous grassland & 20 & 0.119 n.s. & 0.382 n.s. & 0.226 n.s. \\
\hline Calcareous soil & Matgrass sward & 20 & -0.063 n.s. & -0.271 n.s. & -0.167 n.s. \\
\hline Matgrass sward soil & Both & 32 & -0.138 n.s. & -0.227 n.s. & -0.222 n.s. \\
\hline Matgrass sward soil & Calcareous grassland & 16 & 0.291 n.s. & 0.232 n.s. & 0.179 n.s. \\
\hline Matgrass sward soil & Matgrass sward & 16 & -0.438 n.s. & $-0.594 *$ & $-0.594 *$ \\
\hline
\end{tabular}

Significance level: $* * 0.001>P \leq 0.01 ; * 0.01>P<0.05 ;$ n.s. not significant. $D W$ above dry weight above-ground, $D W$ below dry weight below-ground, and $D W$ total Total dry weight 
Fig. 2 Scatter plot of the correlation of Potential Ammonia-oxidising Activity (PAA) and plant dry weight (above- and below-ground) for both species groups on both soil types. Trend lines are included to show the direction of the correlation, and the significance level is indicated $(* P<0.05$, n.s. $=$ not significant)
Correlation PAA with biomass of the plant species on both soil types

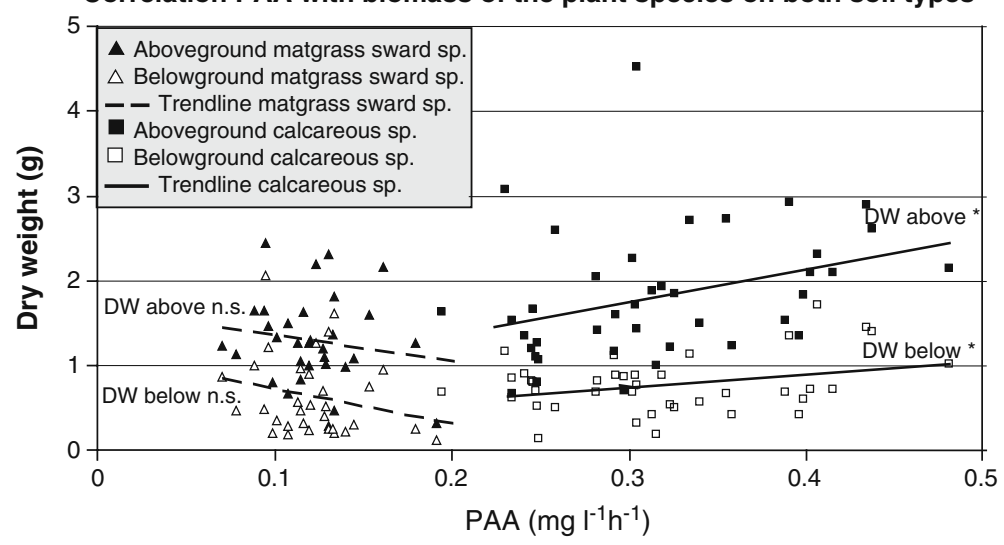

observed absence of the effects of plants on the ammonium and nitrate concentrations in the soils, as both soils contained sufficient nitrogen to sustain plant growth. Nitrate and ammonium availability was checked at regular intervals through pore-water sampling, and no effect of time was found. Sufficient ammonium remained present in the soil during the whole experiment for the ammonia-oxidising community (AOB) (Table 2). Hence, the observed repressed potential activity of the AOB in the presence of plants from the matgrass swards was apparently not due to a lack of ammonium during the growth experiment. We cannot exclude that the significantly lower $\mathrm{pH}$ contributed to the low PAA found in the matgrass sward soil, although earlier field observations showed significant higher PAA at even lower soil $\mathrm{pH}$ values $(<5.1$, Smits et al. 2010).

Except for $H$. umbellatum, all species that grew better on calcareous grassland soil are typical for calcareous grassland. In the field $H$. umbellatum is characteristic for matgrass sward vegetation (SynBioSys, Schaminée et al. 2007). Moreover, biomass production of calcareous plant species was positively correlated to PAA. It is known that nitrate is the main nitrogen form in calcareous grasslands, and calcareous plant species prefer nitrate over ammonium for uptake (Gigon and Rorison 1972) and this is in line with the observed positive correlations. For matgrass plant species no overall correlation between the produced biomass and PAA was found, although on matgrass soil itself, there was a clear negative trend, with significant correlation for below-ground and total biomass. This is in agreement with our hypothesis that matgrass sward species negatively influence nitrification activity, leading to higher soil ammonium concentration and therefore more difficult growth conditions for the plant species themselves. These conclusions seem to be in contrast with the model analysis of Boudsocq et al. (2009) who found that primary production was enhanced by nitrification inhibition in their model for wet tropical savanna. Moreover, in their model analysis, the increase in plant production depends on the relative efficiency of the different recycling pathways of nutrients: nitrification inhibition is more likely to increase primary production if plants prefer ammonium to nitrate (Boudsocq et al. 2009). However, under the current, relatively nutrient-rich circumstances in our grassland gradient, negative effects of the raised amount of ammonium could have caused decreased opportunities for plant growth.

From correlation analyses of data derived from field samples, Stienstra et al. (1994) concluded that nitrification activities determined in grassland soils from a brook valley with different fertilization histories were not related to plant species composition, but only to ammonium availability. The species used in that study are rather common species, and not sufficiently characteristic to be differentiating between different fertilization histories in brook valley grasslands. In our experiment, on the other hand, characteristic plant species for climax grassland vegetation (i.e. matgrass swards and calcareous grassland) were used and the results lead to another conclusion than drawn by Stienstra et al. (1994). In the current experiment plant species composition does affect potential nitrification activity. Furthermore, the results from our experiment substantiate the results 
found by Groffman et al. (1996) who showed that plant species can create differences in microbial activity in soil.

The soils for this experiment were collected in autumn, when nutrient up-take by plants ceases and soil microbial processes rates, e.g. nitrification and mineralization are still high as temperatures have not yet decreased sharply. Mineralization of recently senesced leaf material and active nitrification could explain the observed high standard deviations in nitrate and ammonium concentrations observed in autumn soil samples as compared with analysis on other sampling dates. Potential nitrite-oxidizing activities measured in a non-fertilized, semi-natural grassland, also showed increased nitrification activities at the end of the growing season (Both et al. 1992). A pattern with higher variation in autumn ammonium concentrations was also observed by Zhang et al. (2008) in grasslands in Inner Mongolia, China. Hence, the autumn setting may explain the relatively high variation in nitrate and ammonium concentrations.

The results of the current study confirm studies from Lata et al. (1999, 2000, 2004) on natural and semi-natural vegetation, and enlarge the view that not only crop plant species can exude BNI (Subbarao et al. 2007a, b; Zakir et al. 2008). As was shown by Subbarao et al. (2006, 2007c, 2009a) exudates from the roots of the grass species Brachiaria humidicola and Leymus racemosus were able to influence the activity of nitrifying bacteria. For $B$. humidicola, it was shown by Subbarao et al. (2007b) that ammonium stimulates the synthesis and release of inhibition compounds. In agricultural systems, genetic interventions are currently explored to stimulate efficient use of $\mathrm{N}$ by introducing/improving the BNI capacity in the Triticeae (Subbarao et al. 2009b). Zakir et al. (2008) found an increasing effect of ammonium and plant age on the release of nitrification-inhibiting compounds from the roots of Sorgum bicolor. Lata et al. (1999) discovered a strong correlation between the variation in potential nitrification rate and the characteristics of nitrogen nutrition of grasses in savannas. Mature grassland systems have the ability to inhibit nitrification or have a balanced inhibition-stimulation impact (Lata et al. 2000). Furthermore, Lata et al. (2004) demonstrated that nitrification can be suppressed or stimulated depending on the ecotype of Hypparhenia diplandra. Inhibition of nitrification can play a role in the functioning of these nutrient-poor grassland systems to control $\mathrm{N}$ losses (Lata et al. 2004; Fillery 2007; Phillipot et al. 2009).

In their discussion, Zakir et al. (2008) stated that the ecological significance of repressed nitrification is unknown. We hypothesize however, that repression of nitrification activities could be an adaptation of the nutrient-poor matgrass swards to conserve inorganic $\mathrm{N}$ and use it more efficiently by maintaining it in the less-soluble form of ammonium, thus preventing it from leaching in the form of nitrate (Vitousek et al. 2002; Lata et al. 2004; Herrmann et al. 2005). The findings of the current study fit well into the conceptual model of plant-microbe interactions concerning feedback dynamics (Bever et al. 1997; Reynolds and Haubensak 2008), as the plants turned out to influence the activity of the soil community. The observed inhibition of nitrification can be interpreted as a negative feedback on plant community diversity, under the current raised nitrogen levels due to atmospheric N deposition (Lee and Caporn 1998).

Acknowledgements This research was performed in the framework of the OBN-programme (Dutch Survival Plan for Woodland and Nature) funded by the Ministry of Agriculture, Nature and Food quality. We are grateful to Stichting het Limburgs Landschap for the opportunity to carry out research in the nature reserve Bemelerberg. Furthermore, we want to thank Rein de Waal for his help with the soil classification and Jos Verhoeven for his comments on the manuscript.

Open Access This article is distributed under the terms of the Creative Commons Attribution Noncommercial License which permits any noncommercial use, distribution, and reproduction in any medium, provided the original author(s) and source are credited.

\section{References}

Bakker JP, Berendse F (1999) Constraints in the restoration of ecological diversity in grassland and heathland communities. Tree 14:63-68

Bever JD, Westover KM, Antonovics A (1997) Incorporating the soil community into plant population dynamics: the utility of the feedback approach. J Ecol 85:561-573

Bobbink R (1991) Effect of nutrient enrichment in Dutch chalk grassland. J Appl Ecol 28:28-41

Bobbink R, Lamers LPM (2002) Effects of increased nitrogen deposition. In: Bell JNB, Treshow M (eds) Air pollution and plant life, 2nd edn. Wiley, UK, pp 201-235

Bobbink R, Roelofs JGM (1995) Nitrogen critical loads for natural and semi-natural ecosystems: the empirical approach. Water Air Soil Pollut 85:2413-2418 
Bobbink R, Hornung M, Roelofs JGM (1998) The effects of air-borne nitrogen pollutants on species diversity in natural and semi-natural European vegetation. J Ecol 86:717-738

Both GJ, Gerards S, Laanbroek HJ (1992) The occurence of chemolitho-autotrophic nitrifiers in water-saturated grassland soils. Microb Ecol 23:15-26

Boudsocq S, Lata JC, Mathieu J, Abbadie L, Barot S (2009) Modelling approach to analyse the effects of nitrification inhibition on primary production. Funct Ecol 23:220-223

Britto DT, Kronzucker HJ (2002) $\mathrm{NH}_{4}{ }^{+}$toxicity in higher plants: a critical review. J Plant Physiol 159:567-584

Clark CM, Tilman D (2008) Loss of plant species after chronic low-level nitrogen deposition to prairie grasslands. Nature 451:712-715

De Graaf MCC, Bobbink R, Roelofs JGM, Verbeek PJM (1998) Differential effects of ammonium and nitrate on three heathland species. Plant Ecol 135:185-196

De Graaf MCC, Bobbink R, Smits NAC, Van Diggelen R, Roelofs JGM (2009) Biodiversity, vegetation gradients and key geochemical processes in the heathland landscape. Biol Conserv 142:2191-2201

Dorland E, Bobbink R, Messelink JH, Verhoeven JTA (2003) Soil ammonium accumulation after sod sutting hampers the restoration of degraded wet heathlands. J Appl Ecol 40:804-814

Dupré C, Stevens CJ, Ranke T, Bleeker A, Peppler-Lisbach C, Gowing DJG, Dise NB, Dorland E, Bobbink R, Diekmann M (2009) Changes in species richness and species composition in European acidic grasslands over the past 70 years: the contribution of cumulative nitrogen deposition. Global Change Biol. doi:10/1111/j.1365-2486.2009.01982

Fillery IRP (2007) Plant-based manipulation of nitrification in soil: a new approach to managing N loss? Plant Soil 294:1-4

Gigon A, Rorison IA (1972) The response of some ecologically distinct plant species to nitrate- and to ammonium- nitrogen. $\mathrm{J}$ Ecol 60:93-102

Gopalakrishnan S, Watanabe T, Pearse SJ, Ito O, Hossain ZAKM, Subbarao GV (2009) Biological nitrification inhibition by Brachiaria humidicola roots varies with soil type and inhibits nitrifying bacteria, but not other major soil organisms. Soil Sci Plant Nutr 55:725-733

Groffman PM, Aegan P, Sullivan WM, Lemunyon JL (1996) Grass species and soil type effects on microbial biomass and activity. Plant Soil 183:61-67

Hart SC, Stark JM, Davidson EA, Firestone MK (1994) Nitrogen mineralization, immobilization and nitrification. In: Weaver RW et al (eds) Methods of soil analysis, part 2, Microbial and biochemical properties. Soil Science Society of America, book series 5, Madison, pp 985-1018

Herrmann M, Pust J, Pott R (2005) Leaching of nitrate and ammonium in heathland and forest ecosystems in Northwest Germany under the influence of enhanced nitrogen deposition. Plant Soil 273:129-137

Kleijn D, Bekker RM, Bobbink R, De Graaf MCC, Roelofs JGM (2008) In search for key biogeochemical factors affecting plant species persistence in heathland and acidic grasslands: a comparison of common and rare species. J Appl Ecol 45:680-687

Lata JC, Durand L, Lensi R, Abbadie L (1999) Stable coexistence of contrasted nitrification statuses in a wet tropical savanna system. Funct Ecol 13:762-768
Lata JC, Guillaume K, Degrange V, Abbadie L, Lensi R (2000) Relationships between root density of the African grass Hyparrhenia diplandra and nitrification at the decimetric scale: an inhibition-stimulation balance hypothesis. Proc Biol Sci 1443:595-600

Lata JC, Degrange V, Raynoud X, Maron P-A, Lensi R, Abbadie L (2004) Grass populations control nitrification in savanna soils. Funct Ecol 18:605-611

Lee JA, Caporn STM (1998) Ecological effects of atmospheric reactive nitrogen deposition on semi-natural terrestrial ecosystems. New Phytol 139:127-134

Phillipot L, Hallin S, Borjesson G, Baggs EM (2009) Biochemical cycling in the rhizophere having an impact on global change. Plant Soil 321:61-81

Poschlod P, WallisDeVries MF (2002) The historical and socioeconomic perspective of calcareous grasslandslessons from the distant and recent past. Biol Conserv 104:361-376

Reynolds HL, Haubensak KA (2008) Soil fertility, heterogeneity, and microbes: towards an integrated understanding of grassland structure and dynamics. Appl Veg Sci 12:33-44

Schaminee JHJ, Willems JH (1996) Festuco-Brometea. In: Schaminee JHJ, Stortelder AHF, Weeda EJ (eds) De Vegetatie van Nederland. Deel 3: Plantengemeenschappen van graslanden, zomen en droge heiden. Opulus, Uppsala, pp 145-162

Schaminée JHJ, Stortelder AHF, Weeda EJ (1996) De Vegetatie van Nederland 3. Plantengemeenschappen van graslanden, zomen en droge heiden. Opulus, Uppsala

Schaminée JHJ, Hennekens SM, Ozinga WA (2007) Use of the ecological information system SynBioSys for the analysis of large datasets. J Veg Sci 18:463-470

Smits NAC, Hefting MM, Kamst-van Agterveld MP, Laanbroek HJ, Paalman AJ, Bobbink R (2010) Nitrification along a grassland gradient: inhibition found in matgrass swards. Soil Biol Biochem 42:635-641

Soil Survey Staff (1999) Soil taxonomy. A basic system of soil classification for making and interpreting soil surveys. United States Department of Agriculture \& Natural Resources, Conservation Service. Agriculture Handbook, Number 436

Stevens CJ, Dise NB, Mountford JO, Gowling DJ (2004) Impact of nitrogen deposition on the species richness of grasslands. Science 303:1876-1879

Stienstra AW, Klein Gunnewiek P, Laanbroek HJ (1994) Repression of nitrification in soils under a climax grassland vegetation. FEMS Microbiol Ecol 14:45-52

Subbarao GV, Ishikawa T, Ito O, Nakahara K, Wang HY, Berry WL (2006) A bioluminescence assay to detect nitrification inhibitors released from plant roots: a case study with Brachiaria humidicola. Plant Soil 288:101-112

Subbarao GV, Rondon M, Ito O, Ishikawa T, Rao IM, Nakahara K, Lascano C, Berry WL (2007a) Biological nitrification inhibition (BNI) - is it a widespread phenomenon? Plant Soil 294:5-18

Subbarao GV, Ban T, Kishi M, Ito O, Samejima H, Wang HY, Pearse SJ, Gopalakrishnan S, Nakahara K, Hossain AKMZ, Tsujimoto H, Berry WL (2007b) Can biological nitrification inhibition (BNI) genes from perennial Leymus racemosus (Triticeae) combat nitrification in wheat farming? Plant Soil 299:55-64 
Subbarao GV, Wang HY, Ito O, Nakahara K, Berry WL (2007c) $\mathrm{NH}_{4}^{+}$triggers the synthesis and release of biological nitrification inhibition compounds in Brachiaria humidicola roots. Plant Soil 290:245-257

Subbarao GV, Nakahara K, Hurtado MP, Ono H, Moreta DE, Salcedo AF, Yoshihashi AT, Ishikawa T, Ishitani M, Ohnishi-Kameyama M, Yoshida M, Rondon M, Rao IM, Lascano CE, Berry WL, Ito O (2009a) Evidence for biological nitrification inhibition in Brachiaria pastures. PNAS 106:17302-17307

Subbarao GV, Kishii M, Nakahara K, Ishikawa T, Ban T, Tsujimoto H, George TS, Berry WL, Hash CT, Ito O (2009b) Biological nitrification Inhibition (BNI) - is there potential for genetic interventions in the Triticeae? Breed Sci 59:529-545

Swertz CA, Schaminee JHJ, Dijk E (1996) Nardetea. In: Schaminee JHJ, Stortelder AHF, Weeda EJ (eds) De Vegetatie van Nederland. Deel 3: Plantengemeenschappen van graslanden, zomen en droge heiden. Opulus, Uppsala, pp 263-286

Van den Berg LTL, Dorland E, Vergeer P, Hart MAC, Bobbink R, Roelofs JTM (2005) Decline of acid-sensitive plant species in heathland can be attributed to ammonium toxicity in combination with low $\mathrm{pH}$. New Phytol 166:551-564

Van den Berg LJL, Peters CJH, Ashmore MR, Roelofs JGM (2008) Reduced nitrogen has a greater effect than oxidised nitrogen on dry heathland vegetation. Environ Pollut 154:359-369
Van der Meijden R (2005) Heukels' flora van Nederland. $23^{\mathrm{e}}$ druk. Wolters-Noordhoff bv Groningen, NL

Verhagen FJM, Duyts H, Laanbroek HJ (1992) Competition for Ammonium between nitrifying and heterotrophic bacteria in continuously percolated soil columns. Appl Environ Microbiol 58:3303-3311

Vitousek PM, Hattenschwiler S, Olander L, Allison S (2002) Nitrogen and nature. Ambio 31:97-101

WallisDeVries MF, Poschlod P, Willems JH (2002) Challenges for the conservation of calcareous grasslands in northwestern Europe: integrating the requirements of flora and fauna. Biol Conserv 104:265-273

Willems JH (1990) Calcareous grasslands in Continental Europe. In: Hillier SH, Walton DHW, Wells DA (eds) Calcareous grasslands. Ecology and management. Bluntisham Books, Bluntisham, pp 3-10

Willems JH (2001) Problems, approaches, and results in restoration of Dutch calcareous grasslands during the last 30 years. Restor Ecol 9:147-154

Zakir HAKM, Subbarao GV, Pearse SJ, Gopalakrishnan S, Ito O, Ishikawa T, Kawano N, Nakahara K, Yoshihashi T, Ono H, Yoshida M (2008) Detection, isolation and characterization of a root-exuded compound, methyl 3(4-hydroxyphenyl) propionate, responsible for biological nitrification inhibition by sorghum (Sorghum bicolor). New Phytol 180:442-451

Zhang X, Wang Q, Linghao L, Han X (2008) Seasonal variations in nitrogen mineralization under three land use types in a grassland landscape. Acta Oecol 34:322-330 